研 究

\title{
吸引工具による局部電解めつきにおける加工条件の影響
}

佐藤敦*, 夏 恒*

\section{Influence of Machining Conditions on Local Electroplating with Suction Tool}

\author{
Atsushi SATO, Wataru NATSU
}

\begin{abstract}
Electroplating is used, for example, for corrosion protection, surface hardening, and metal thin-film manufacturing. In conventional electroplating, the workpiece is immersed in the plating solution, and the whole contact surface is plated. Therefore, the mask operation and the removal of unnecessary plating film are needed for local plating in cases such as ornament plating. However, these additional processes would lead to a substantial increase in processing time and cost. In this research, an approach to realizing local electroplating by using a suction tool, with which the electrolyte is confined in the area between the tool electrode and workpiece, was carried out and the influence of machining conditions on the plating characteristics was investigated. The experimental results show that the maskless local electroplating can be performed, and the influences of the tool material, current density and the scanning speed were clarified. The plating of patterns such as characters is possible with the proposed method.
\end{abstract}

Key words: Electroplating, suction tool, maskless, film forming, plating characteristics

\section{1 緒 論}

電解めっきは，金属イオンが含まれているめっ き液に工作物を浸漬して通電し，工作物の表面に 金属薄膜を被覆する作業である. 用途には, 装飾・ 防食，表面硬化，金属薄膜製造等がある．工作物 をめっき浴槽に浸漬する電解めっき法では, めっ き液と工作物が接触する面全体がめっきされる. よって, 部品の機能として, または装飾の目的と して，工作物表面の一部にのみめっきが必要な場 合には，マスキング処理や不要な金属薄膜の除去 作業が必要である ${ }^{1)}$. これらの作業等は, コスト や時間を要する，さらに，めっき液は有毒・污染 物質を含んでいる場合が多く，法令によって規制 されている ${ }^{2)}$. そのため, 部分めっきでのめっき 浴槽の使用は多量の污染物質を用いることにつな がり，環境に負荷を与える。

*東京農工大学 工学府 (東京都小金井市中町2-2416)
めっき浴槽を用いない付加加工について，竹内 $ら^{3)}$ は電解液噴流, Kunieda ら ${ }^{4)}$ は電解液ジェッ 卜を利用して工作物を陰極にし，マスクレスな付 加加工を実現している．しかし，それらは腐食性 を有する電解液の飛散を招き, 周囲の機器や環境 に悪影響を与える恐れがある.

一方, 電解加工による形状創成において, 加工 領域以外に電解液を存在させない方法が検討され ている. Yamamura ら ${ }^{5)}$ は二重の円筒形状を持つ工 具を用い，加圧ポンプにより極間に供給したエッ チング夜を吸引ポンプで回収し，ローカルウェッ トエッチングを実現している.また, 筆者ら ${ }^{6}$ は, 電解液に加圧せず，工具中心部から電解液を吸引 し, 極間距離検知機能を有しながら加工領域を限 定できる電解液吸引工具を提案している.

そこで, 本研究はマスクレスで部分めっきを実 
現するため, Endo ら の) と同様な原理を持つ電解液 吸引工具(以後, 吸引工具と呼称)を利用し, めっ き液の飛散がなく, 環境にやさしいめっき法への 適用を試みた。 なお，本方法の成膜特性を把握寸 るため, 電極材料, 電流值, 走査速度等の加工条 件がめっき面に及ぼす影響を実験的に調べた。

\section{2 吸引工具の原理と実験装置}

\section{1 吸引工具の原理}

吸引工具の原理は，ベルヌーイの定理を用いて

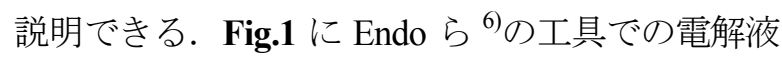
循環の概要を示す. Fig.1(a)のように，工具と工作 物間の距離が大きい場合は工具外周から流入する 空気の流速が遅く, 電解液の流出口における圧力 が大きく低下しない，そのため，工具と工作物間 の距離が大きい場合は，外筒部の電解液が流出し ない. 一方, 距離が小さくなると, 流入する空気 の流速が速くなり，流出口の圧力が大きく低下寸 るため, Fig.1(b)のように外筒部の電解液を吸引し て吸引穴に向かって流れるようになる。つまり， 極間距離が狭くなったときの夕, 電解液が電極端 面に対向している工作物の部分に流れるため, め っき液と工作物の接触領域を限定できる.

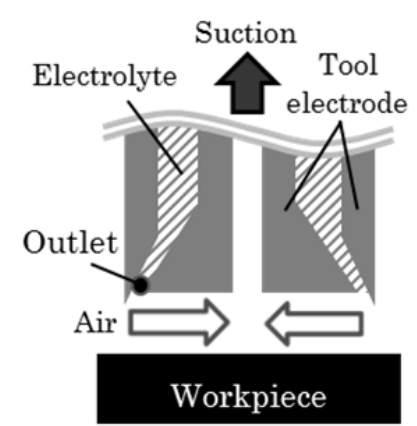

(a) For broad gap-width

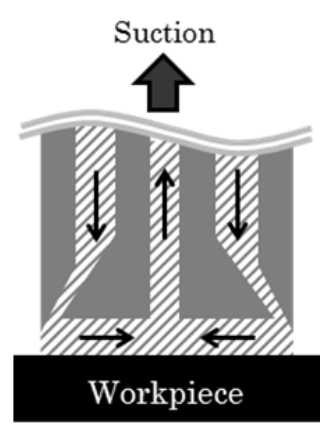

(b) For narrow gap-width
Fig.1 Schematic view of electrolyte circulation

\section{2 実験装置と実験方法}

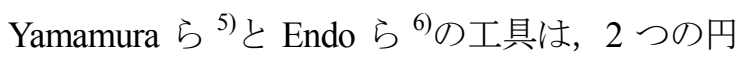
筒で電極を形成しており，1 $\mathrm{mm}$ 角程度の小さい 領域での部分めっきの実現が困難である.そこで, 本研究では電極を棒状として, アクリル部品で電 極を囲うことで加工領域を小さく限定させる工具 を製作している．Fig.2(a)に実験装置の概要図,

Fig.2(b) に工具先端の拡大図，Fig.2(c)に工具の底
面図を示す.

この実験装置は工作物を XYZ ステージ上に固 定し, 吸引工具の内部で硝酸銅水溶液がめっき液 として循環することで, 工作物の表面に電解銅め つきを施すものである. 吸引工具は, ワイヤ放電 加工機で所要の形状まで加工した厚さ $1 \mathrm{~mm}$ の金 属板を電極とし， Fig.2(a)に示すように2つのアク リル部品により電極を囲うことで製作した．この 工具では，吸引ポンプをつなぐことでタンク内の めっき液を吸引し, Fig.2(b)のように工具先端部の みでめっき液が循環する，その際，めっき液が電 解液の流出口から吸引され, Fig.2(c)に示寸電解液 が底面領域を通って吸引口へ流入する。 この底面 領域には $1 \mathrm{~mm}$ 角の電極が存在するため, 局所的 なめっきが実現できる，吸引ポンプには，エアー ポンプ(IWAKI 社製, APN-60-W), 加工電源には バイポーラ電源(TAKASAGO 社製, BWS 120-2.5) を用いた。使用した硝酸銅水溶液の温度は約 $22^{\circ} \mathrm{C}$ であり，極間距離 $70 \mu \mathrm{m}$ での質量流量を測定する と, 本実験装置で極間に流れるめっき液の質量流 量は約 $0.24 \mathrm{~g} / \mathrm{s}$ であった，極性は，工具電極を陽 極, 工作物を陰極とした。本研究では, パルスオ フ期間中に電解生成物や気泡を除去することを目 的とし，定電流モードでパルスめっきを行った. なお，めっきの場合，工作物（陰極）表面の電流 密度が成膜特性に直接影響するため, パラメータ として電流值より電流密度を用いることが望まし い. しかし, 本研究のめっき領域は $1 \mathrm{~mm}$ 角の工具 (陽極) 底面より多少広がり, 条件によっても異 なるので, 陽極電流密度は求められるが, 工作物 表面の電流密度の算出が困難である. そこで, 本 研究では, 設定電流值をパラメータとして用いる ことにする. その場合, 電流值を陽極の底面積 $\left(0.01 \mathrm{~cm}^{2}\right)$ で割った值は陽極電流密度となる. め っきでは, 接触面が合金となっている場合, 密着 が良い ${ }^{7)}$ ，そのため，工作物には，めっきした銅 の密着性を確保するため, 真鈴(銅 : 約 $60 \%$, 覀 鉛 : 約 $40 \%$ )を使用した. 工作物表面は, 粒径 0.25 $\mu \mathrm{m}$ ダイヤモンドスラリーを用いて機械研磨で前 加工した. めっき条件を Table 1 に示す. なお, 本論文の全実験では, めっき中における Z 軸の制 御は行っていない. 


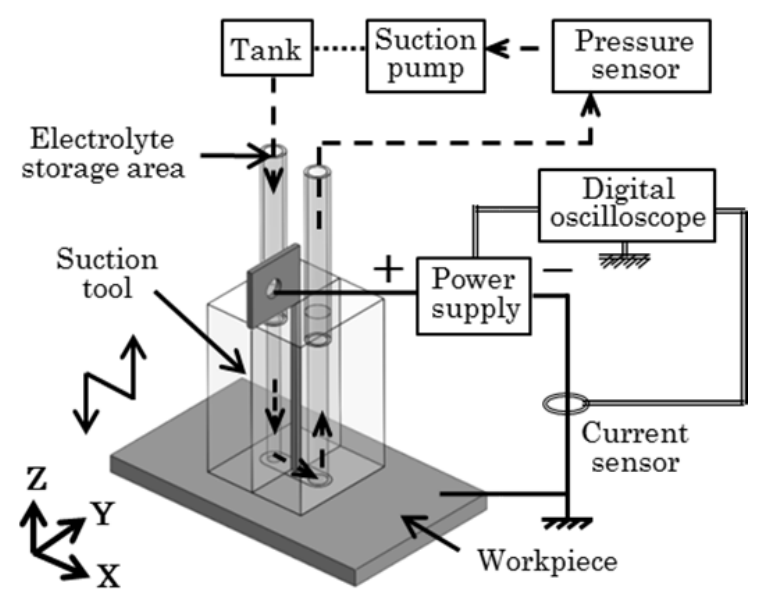

(a) Overview of experimental setup

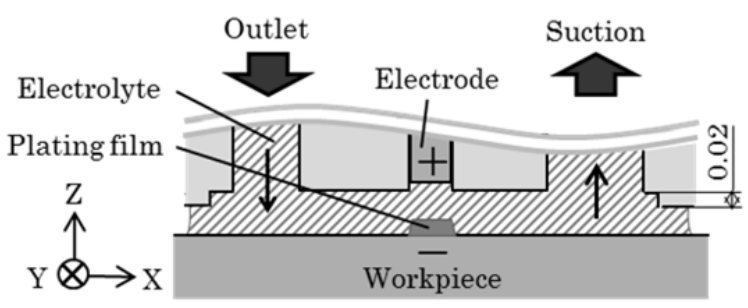

(b) Enlarged view of tool tip

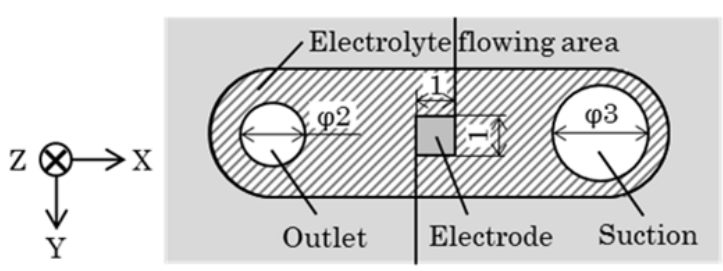

(c) Bottom view of tool

Fig.2 Experimental setup for local electroplating

Table 1 Experimental conditions for plating

\begin{tabular}{|c|c|}
\hline Plating solution & $22 \mathrm{wt} \% \mathrm{Cu}\left(\mathrm{NO}_{3}\right)_{2} \mathrm{aq}$ \\
\hline Workpiece material & Brass \\
\hline Tool material & Brass, Titanium \\
\hline Gap width $[\mu \mathrm{m}]$ & 70 \\
\hline Power supply & Pulsed constant current \\
\hline Pulse period $[\mathrm{ms}]$ & 50 \\
\hline Pulse width $[\mathrm{ms}]$ & 5 \\
\hline
\end{tabular}

\section{3 めっき膜の評価方法}

めっき膜の品質要素には, 密着性, 膜厚, 欠陥, 洗浄・乾燥後におけるしみの有無がある ${ }^{8)}$. 本研 究では, めっき膜厚と均一性は厚さと表面粗さ, 欠陥はめっき膜の外観観察から評価する. 厚さは, めっき膜を輪郭形状測定器 (Mitutoyo 社製 CV-3100S4)により，X，Y 方向の輪郭形状をそれ ぞれ $0.1 \mathrm{~mm}$ 間隔で 5 回測定し, 求めた厚さを平 均した. 表面粗さは, 評価領域内の算術平均粗さ の平均值とした. 表面粗さの評価領域は, 成膜領 域を中心とした $1 \mathrm{~mm} \times 1 \mathrm{~mm}$ 内である.

\section{3 電極材料が電極消耗特性へ及ぼす影響}

従来の電解銅めつきでは, めつき液への金属イ オンの補給を目的とし, 純度の高い電気銅等を可 溶性陽極として使用するのが一般的である ${ }^{9}$. 一 一 方，陽極の走查による部分めっきの場合，陽極消 耗による極間距離の変化がめっき特性に影響を及 ぼす恐れがある，よって，本研究ではまず，消耗 しにくい材料にチタン(純チタン), 消耗しやすい 材料に真鍮(銅: $60 \%$, 亜鉛: $40 \%$ )を電極材料として 用い，電極消耗特性を調べる. チタンは，表面に 金属の溶出を妨げる密着性の酸化皮膜( 不動態皮 膜)を生成し, 特に電解加工しにくい材料として知 られている ${ }^{10)}$. チタン電極は電極消耗が少ないと 考えられるが, パルス電源において陽極溶出は依 然として生じる，一方，真鍮は被削性に優れ，電 極を製作しやすい特徴を有する.

\section{1 電極長さ消耗率の算出方法}

両電極材料の消耗特性を比較するため, 工具を 走査せずにめっきを行い, (1)式によって電極長さ 消耗率 $w_{l}$ を算出し, 比較することとした.

$$
w_{l}[\%]=\frac{l_{e}}{l_{f}} \times 100
$$

ただし, $l_{e}$ は電極消耗長さ, $l_{f}$ はめっき膜の厚 さである. 電極消耗長さは, めっき前後で電極底 面の $\mathrm{X}, \mathrm{Y}$ 方向における輪郭形状を $0.1 \mathrm{~mm}$ 間隔 で各 5 回測定し, 算出した $\mathrm{Z}$ 軸方向の差である.

\section{2 電極消耗特性の比較}

Fig.3 に両電極材料でのめつき膜の厚さと電極 消耗長さ, Fig.4 に電極長さ消耗率を示す. 電流值 は $50 \mathrm{~mA}$, 通電時間は $30 \mathrm{sec}$ である. エラーバー は, 3 回の実験の最大值と最小值である. 


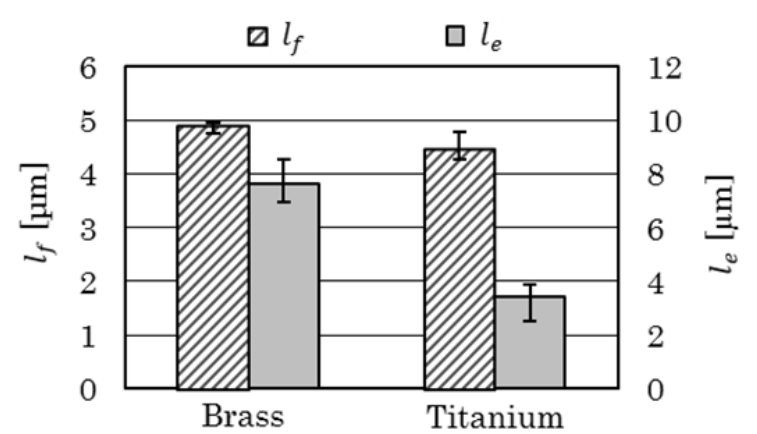

Fig.3 Effect of electrode material on $l_{f}$ and $l_{e}$

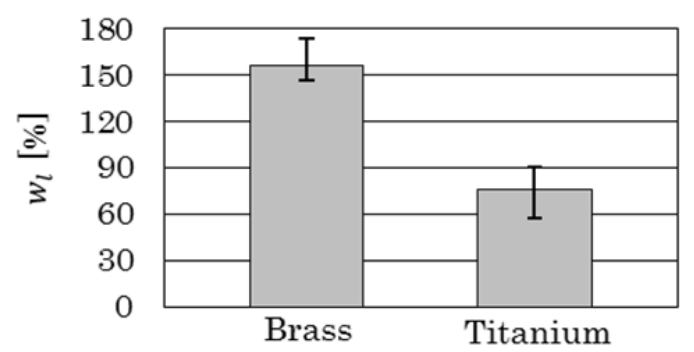

Fig.4 Effect of electrode material on $w_{l}$

Fig.3 より, 両電極材料ともめっき膜の厚さに大 きな違いはないが，真鍮の電極消耗長さはチタン の約 2 倍である.つまり, Fig.4 のように真鍮の電 極長さ消耗率は, チタンの約 2 倍となる.

\section{4 両電極材料の成膜特性}

通常, めっき膜の厚さは, 電流密度と時間に比 例する ${ }^{7)}$. そのため, 成膜速度の向上には電流值 増大が有効であるが，電流密度の過大は，膜表面 における久陥の発生原因となる，本章では，両電 極材料の電流值と膜厚の関係を調べ，成膜特性を 比較した結果について述べる.

\section{1 電流値と膜厚の関係}

両電極材料における電流值と厚さの関係を

Fig.5, 電流值と表面粗さの関係を Fig.6 に示す.

通電時間は $10 \mathrm{sec}$ であり，エラーバーは 3 回の実 験の最大值と最小值である.

Fig.5 より, 両電極材料とも電流值の増加に伴っ て厚さが厚くなることがわかる．また，200 mA 以上では真鍮電極における厚さがチタンの $2 〜 4$ 倍程度になるが， $50 \mathrm{~mA}$ 以下では両方の電極とも 厚さが同程度かつ再現性が良好である。さらに，
両電極材料とも厚さが同程度である $100 \mathrm{~mA}$ 以下 で Fig.6をもとに表面粗さを比較すると, チタン 電極の方が真鍮電極よりも表面が粗い．よって, 真鍮電極の方がチタン電極より膜厚の均一性に優 れることがわかる。

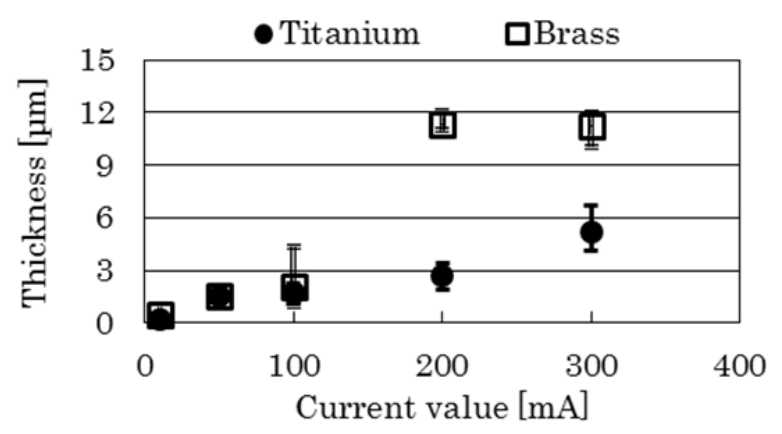

Fig.5 Relation between thickness and current value

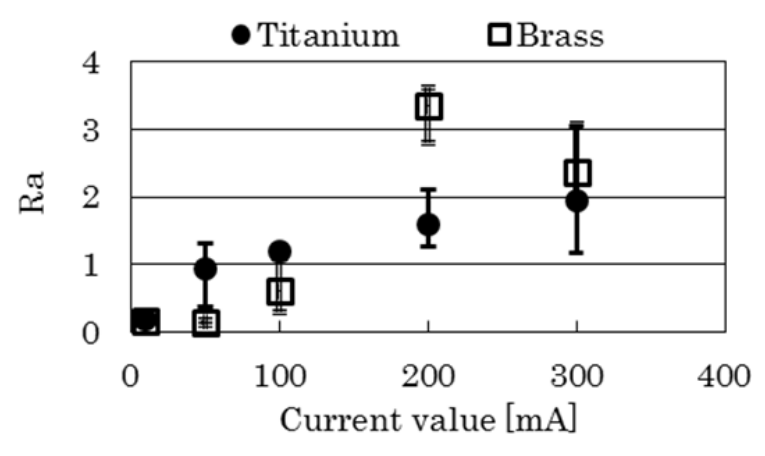

Fig.6 Relation between Ra and current value

実用化のため, めつき特性について電流効率で 考察すべであるが，めつき皮膜の膜厚は，陰極表 面の電流密度, 水素の発生, 電解液の流量と温度 上昇のさまざまな影響を受け，また，本研究の銅 めつきの原子価も断定できないため, 現段階での 考察が困難である.

\section{2 電極材料が膜厚の均一性に及ぼす影響}

$50 \mathrm{~mA}, 100 \mathrm{~mA}, 200 \mathrm{~mA}$ におい, めっき液 の流れ方向のめっき膜厚の均一性を両電極材料で 比較した結果を Fig.7 に示す.

Fig.7(a)と(b)を比較すると, $50 \mathrm{~mA}$ ではめっき液 の流れ方向における膜厚の変動が比較的小さいが, $100 \mathrm{~mA}$ 以上になると変動が大きくなることがわ かる. また, $50 \mathrm{~mA}, 100 \mathrm{~mA}$ における膜厚に着目 すると, チタン電極では特にめっき膜の両端部で 厚さが増加した. これらの原因の詳細についてさ 
らなる実験と分析は必要となるが，チタン表面を 覆う不動態膜の影響により極間抵抗が真鍮よりも 大きくなり, 電極角部で電界集中が生じるためで あると考えられる．実際，めっき中の電圧值を観 測すると, 電流值により異なるが真鍮電極で 1 2 $\mathrm{V}$ 程度, チタンで $20 \sim 40 \mathrm{~V}$ 程度であり, チタンの 方がはるかに極間抵抗が大きかった。

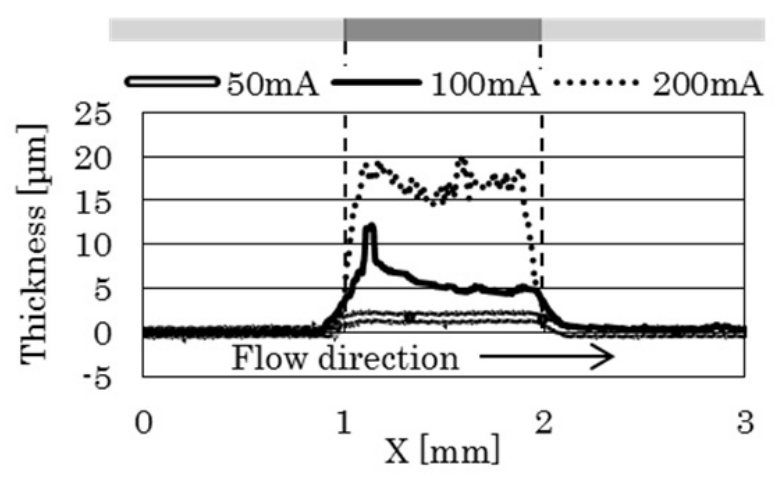

(a) Film shape by using a brass electrode

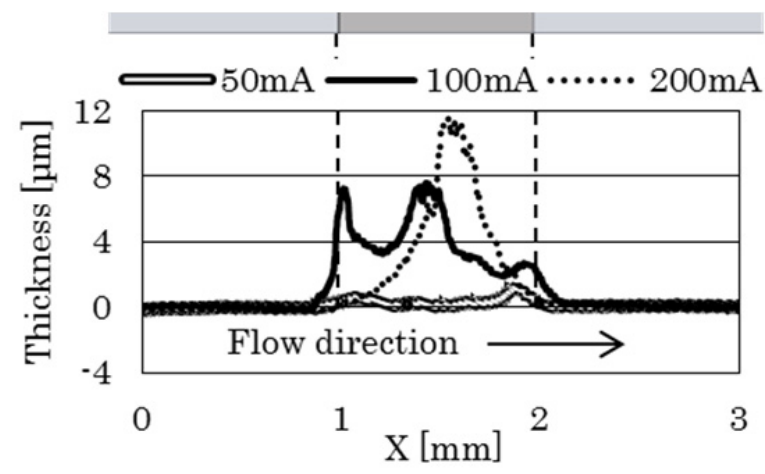

(b) Film shape by using a titanium electrode

Fig.7 Comparison between film shapes with different electrode material in $\mathrm{X}$ direction

一方，本吸引工具は，めつき液の流れが軸対称 でないため, 液の流れ方向がめっき膜形状に影響 する可能性がある，そこで，めっき液の流れ方向 と垂直な方向においてもめっき膜厚の均一性を両 電極材料で比較した. 比較結果を Fig.8 に示寸.

Fig.8 より, めっき液の流れ方向と垂直な方向に おいても流れ方向と同様の傾向が見られることが わかる.よって, 液の流れ方向がめっき膜形状に 与える影響は小さいと考えられる.

\section{3 めっき膜外観の観察結果}

本節では, 両電極とも厚さのばらつきが少なく,

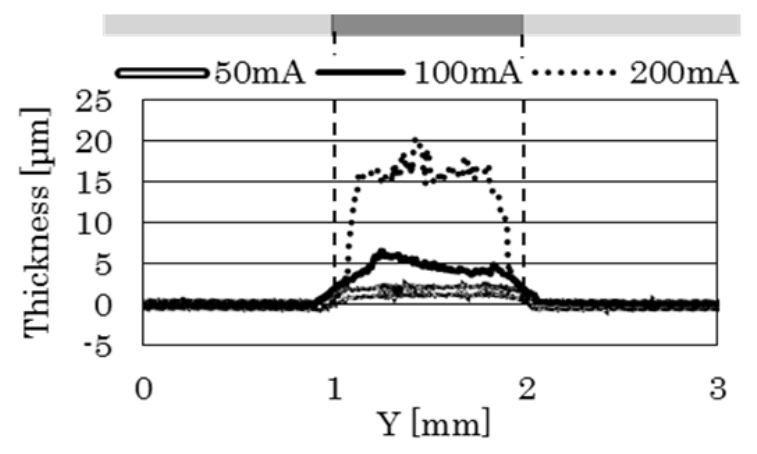

(a) Film shape by using a brass electrode

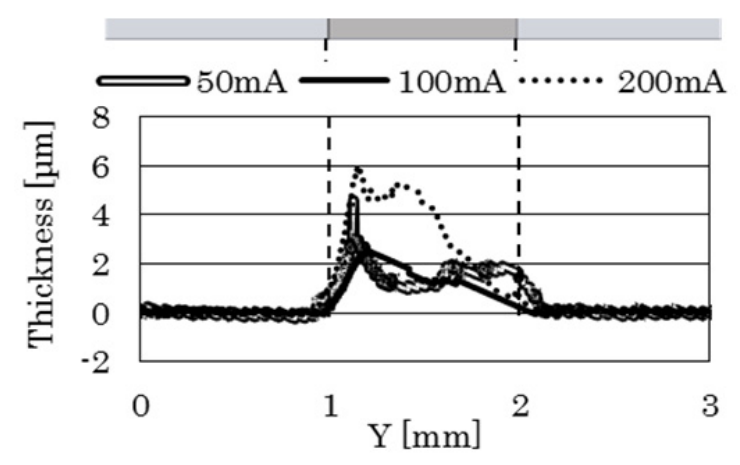

(b) Film shape by using a titanium electrode

Fig.8 Comparison between film shapes with different electrode material in $\mathrm{Y}$ direction

表面粗さに比較的優れる $50 \mathrm{~mA}$ でめっき膜外観 を比較した. Fig.9に比較結果を示す.

Fig.9(a)を見ると，めっき膜表面に黒い斑点が見 られるが, 前述のように真鍮を用いた $50 \mathrm{~mA}$ での めっき膜は比較的均一性が良好である。これは, 焦げの特徵である粗いめっきと一致しないことか ら，黒い斑点はめっき液による腐食であると考え られる.よって, 真鍮電極の場合ではピットや焦 げといった欠陥がなく, 良好なめっき表面を得ら れていることがわかる。しかし，Fig.9(b)のチタン 電極では，電極底面の直下領域全体にはめっきで きておらず，焦げと呼ばれる欠陥が観察される. 電極底面の直下領域全体にめっきできていない原 因には，めっき中の高い電圧值により大量に発生 した水素がめっきの妨げとなったことが考えられ る. また, 焦げの原因には, 発熱によるめっき液 温度の上昇や高い陰極電流密度による水素放電が 考えられる ${ }^{11)}$.このように，めっき膜外観におい ても真鍮電極はチタン電極よりも優れている. 


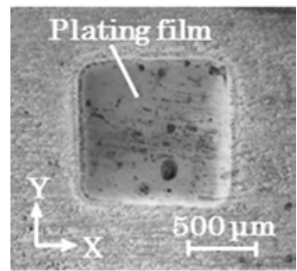

(a) Brass electrode

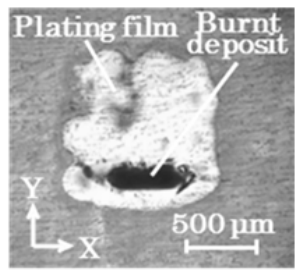

(b) Titanium electrode
Fig.9 Comparison of film appearance on $50 \mathrm{~mA}$

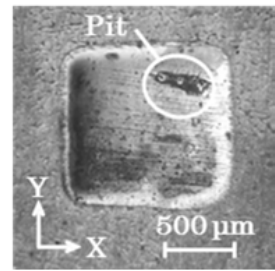

(a) $100 \mathrm{~mA}$

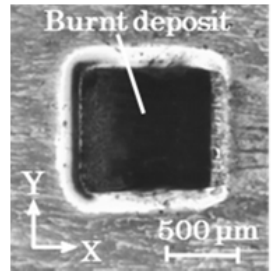

(b) $200 \mathrm{~mA}$
Fig.10 Film appearance under $100 \mathrm{~mA}$ and $200 \mathrm{~mA}$ by using a brass electrode

Fig.10 に真鍮電極での電流值 $100 \mathrm{~mA}$ と $200 \mathrm{~mA}$ におけるめっき膜外観を示す．Fig.10のように， 真鍮電極における $100 \mathrm{~mA}$ でピット, $200 \mathrm{~mA}$ で焦 げが生じる，これらの久陥が生じる原因には，主 に陰極電流密度の過大によって陰極で発生した水 素や水素放電が考えられる ${ }^{11)}$. 真鍮電極を用いた $50 \mathrm{~mA}$ で，電流が流れた面積をめっき膜 $\mathrm{X}, \mathrm{Y}$ 方 向におけるめっき膜の幅の積とすると, 電流が流 れた面積は約 $1.32 \mathrm{~mm}^{2}$ であった. このときの陰極 電流密度は約 $38 \mathrm{~mA} / \mathrm{mm}^{2}$ であり, 従来の酸性銅め つきの標準值の約 100 倍〜 130 倍に相当する ${ }^{12}$.

\section{5 走査加工における成膜特性の比較}

本研究で提案する吸引工具を走査すれば, 複雑 な模様のめっき膜を形成できる，本章では，工具 を走查し，前章と同様に両電極材料で成膜特性を 比較した結果について報告する。本章における全 ての実験は工具を 1 回走查させて実施したもので あり，めっき膜の重初合わせはしていない.

\section{1 走查加工面の評価方法}

走查加工面における膜厚さを評価するため, 工 具を X 方向に $3 \mathrm{~mm}$ 走査し, Fig.11 に示寸評価領 域内を評価した。点線部を輪郭形状測定器で測定 し，めっき膜中心 $2 \mathrm{~mm}$ の範囲を評価した.

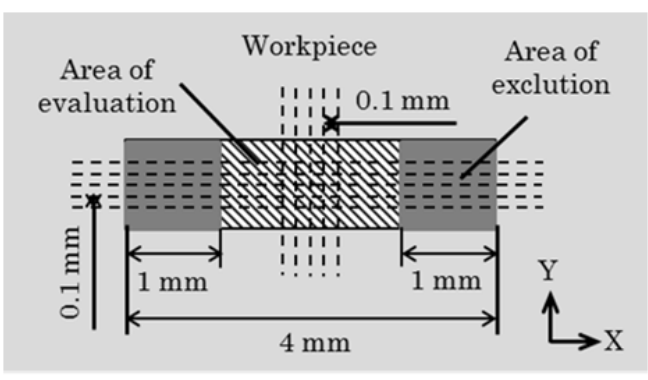

Fig.11 Method of film evaluation

\section{2 走查速度と膜厚の関係}

文字などのパターン膜を速く形成する場合, 適 切な電流值で工具を速く走査する必要がある. そ こで, 両電極材料における走査速度と膜厚の関係 を調べた. 走査速度と厚さの関係を Fig.12, 走查 速度と表面粗さの関係を Fig.13 に示す.電流值は, 厚さの再現性が良好かつ真鍮電極でめっき膜の外 観に優れる $50 \mathrm{~mA}$ である. エラーバーは 3 回の実 験の最大值と最小值である.

Fig.12 を見ると, 両電極とも同程度の厚さであ り，厚さと走査速度が反比例の関係にあった。さ らに Fig.13より, 真鍮電極での表面粗さは走查速 度に関わらずチタン電極より優れる，そして，チ タン電極では走查速度が遅くなるにつれて表面が

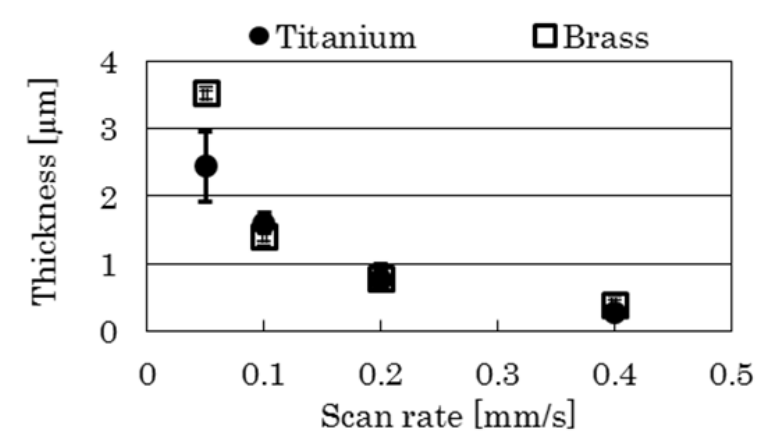

Fig.12 Relation between thickness and scan rate

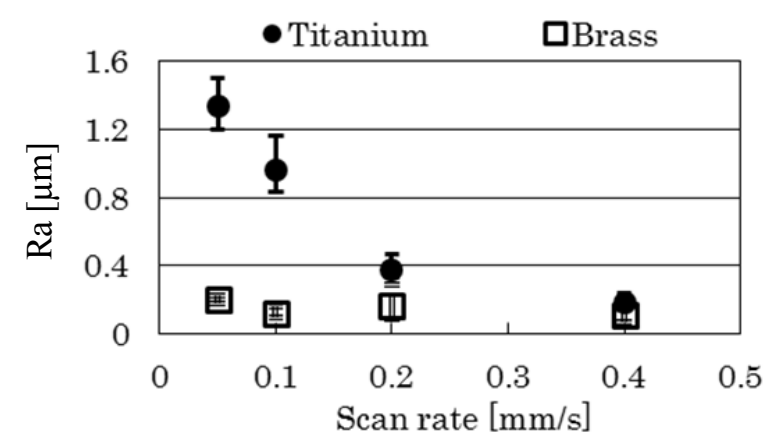

Fig.13 Relation between $\mathrm{Ra}$ and scan rate 
粗くなる一方，真鍮では本実験条件の範囲におい ては， Raが 0.1 0.2 $\mu \mathrm{m}$ となっており，良好な表 面粗さを維持している.

\section{3 走査が膜厚の均一性に及ぼす影響}

走査速度 $0.05 \mathrm{~mm} / \mathrm{s}$ と $0.4 \mathrm{~mm} / \mathrm{s}$ において, めっ き膜の均一性を両電極材料で比較した. Fig.14 に 走查方向, 走查方向と垂直な方向の膜形状を示寸.

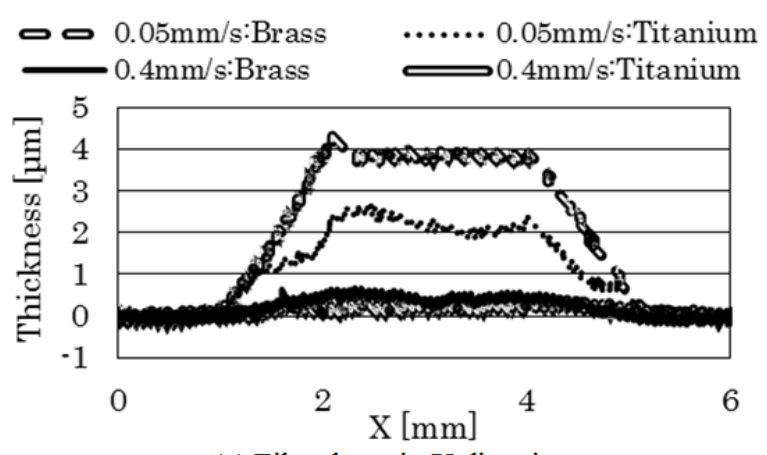

(a) Film shape in $\mathrm{X}$ direction

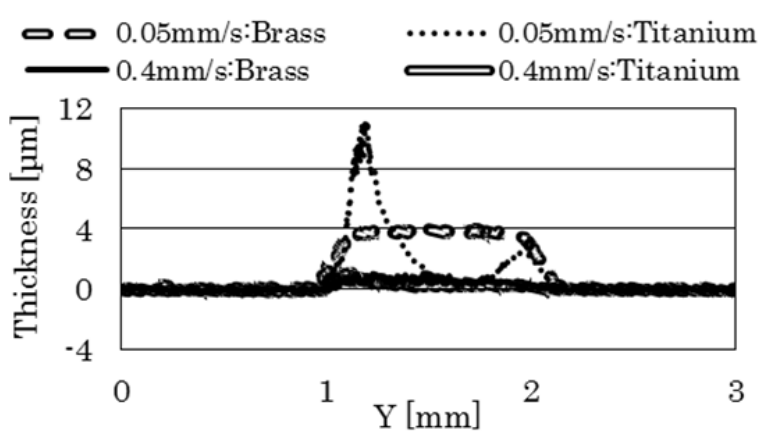

(b) Film shape in $Y$ direction

Fig.14 Film shape under different tool material and scan rate

Fig.14(a)より，走査方向の評価領域内では，走 査速度によらず両電極材料とも厚さの変動幅が 1 $\mu \mathrm{m}$ 以内であり, 膜厚の均一性に違いはあまり見 られない，しかし，Fig.14(b)を見ると，走查方向 と垂直な方向では，走査しない場合と同様，チ夕 ン電極でめっき膜両端部における厚さの上昇が見 られた。 また，チタン電極を用いた $0.05 \mathrm{~mm} / \mathrm{s}$ で はめっき膜中央から両端部にかけての厚さの変動 幅が最大で $10 \mu \mathrm{m}$ 程度, 真鍮電極では $1 \mu \mathrm{m}$ 以内 であり, 電極材料による均一性への影響が大きい. このように，真䤼電極では走查速度によらず均一 にめっき膜が形成される一方, チタン電極では比 較的遅い走查速度でめっき膜両端部における厚さ の上昇が著しい. Fig.14(b) に示す Y 方向の膜形
状では，チタン電極を用いた走査速度 $0.05 \mathrm{~mm} / \mathrm{s}$ でめっき膜の厚さ上昇が左端に傾いている。この 傾きは，実験でたびたび見られるものであり，傾 きの方向がいつも同じというわけではない，その ため, 膜形状の傾きは電解液の流孔状態が実験ご とにばらつくことで生じているものと考えられる.

\section{4 走査速度がめっき膜外観に与える影響}

Fig.15のように, チタン電極を用いた $0.05 \mathrm{~mm} / \mathrm{s}$ でめっき膜外観に焦げが見られた。しかし，比較 的走查速度の速い $0.4 \mathrm{~mm} / \mathrm{s}$ では, 焦げやピットな どの久陥が見られなかった，一方，真鍮電極では 走査速度によらずめっき膜に電流密度の過大によ る欠陥を生じなかった。

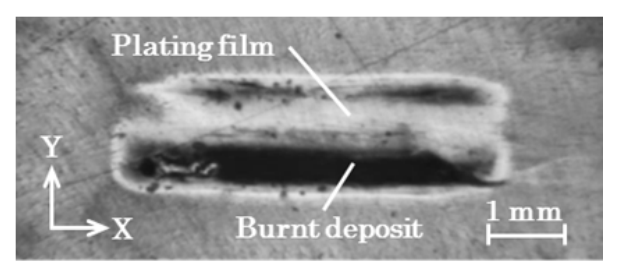

Fig.15 Appearance at $0.05 \mathrm{~mm} / \mathrm{s}$ with titanium electrode

\section{5 パターン膜の形成}

吸引工具を用いることでめつき領域を限定でき るが，実際にパターン膜の形成に適用できるかを 検証する必要がある，そこで，めっき膜の品質が 良好な真鍮電極を用い, 走査速度 $0.4 \mathrm{~mm} / \mathrm{s}$, 電流 值 $50 \mathrm{~mA}$ でパターン膜の形成を試みた. Fig.16 に 形成したパターン膜の外観を示寸. めっき膜の厚 さは, 約 $0.4 \mu \mathrm{m}$ である.

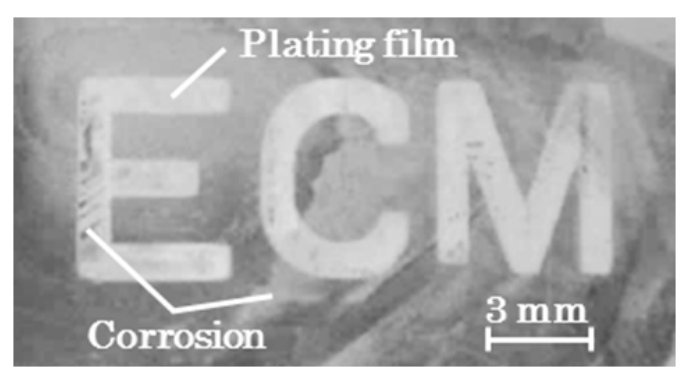

Fig.16 Pattern shaped by tool scanning

写真のように，めっき液による腐食が見られる が，文字が明確に認識できる，よって，工具を走 査させることで文字などのパターン膜の形成が可 能である. 


\section{6 走査回数が成膜特性に及ぼす影響}

近年，新製品開発の試作品を迅速かつ安価に製 造する機器として 3D プリンタが注目されている 13,14). Kunieda $~^{4}{ }^{4)}$ は, 電解ジェット加工において 除去と逆の極性とし，部分的な付着加工ならびに 積層造形を実現している，本研究はめっき領域を 限定させるものであり，同様にめつき膜を積層さ せて積層造形できることが考えられる。しかし， 工作物表面の状態とめっき膜表面の状態が異なる ため, 積層加工では成膜特性が異なる可能性があ るので，走查回数が成膜特性に及ぼす影響を調心゙ た.

\section{1 走査回数と膜厚の関係}

通電時間を $1 \mathrm{~min}$ とし，走査速度と走查回数を 変化させて実験を行った. Fig.17 に走查回数と膜 厚の関係を示寸.電極は真鍮電極, 電流值は $50 \mathrm{~mA}$ である. 走查回数 1 回は X+方向に 1 回走查，走 查回数 2 回では走查速度を 2 倍にして 1 往復, 走 查回数 3 回では走查速度を 3 倍にして 1 往復半走 查している. エラーバーは 3 回の実験の最大值と 最小值である.

Fig.17 より，めっき膜を積層させても厚さと表 面粗さにあまり影響しないことがわかる。なお， 積層させた場合の問題点として層ごとの密着性が あると考えられるが，本研究では密着性の測定と 評価を行っていない.

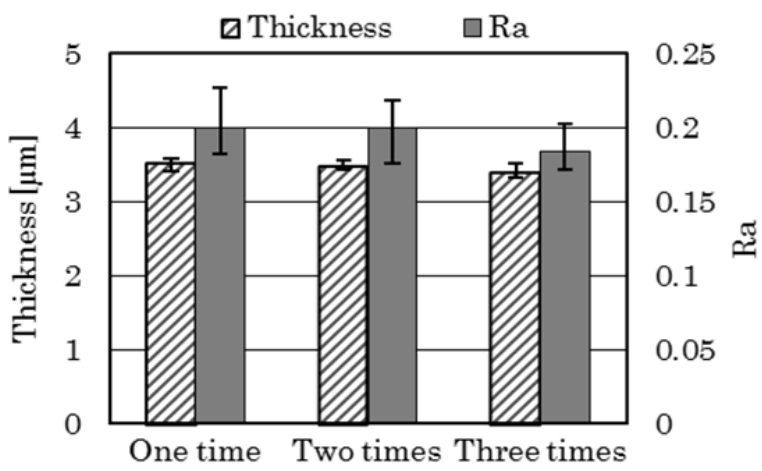

Fig.17 Relation between scanning times and film thickness

\section{2 積層がめっき膜外観へ与える影響}

積層がめつき膜外観へ与える影響を調べるため, 1 回走査と 3 回走査でのめっき膜外観を比較した. それぞれのめっき膜外観を Fig.18 に示す. いくつ
かの黒斑が図中のめっき膜表面に見られる.また， 一回走査では三回走査した場合よりもめっき表面 に比較的多くの黒斑が見られる. 電解銅めっきで は，陰極電流密度の過大によって表面が暗赤色の めっきになり，ピットやざらつきが発生する ${ }^{11)}$. そのため，黒斑が陰極電流密度の過大によるもの であれば，双方の表面粗さに大きな違いが生じる はずである.しかし，前節 6.1 の Fig.17 を見ると 表面粗さに大きな違いは見られない。よって,

Fig.18における黒斑は陰極電流密度の過大による 欠陷ではなく，めっき液による腐食であると考え られる。

Fig.18 より, 積層させても膜表面に欠陥が生じ ないことがわかる，よって，本研究の実験範囲で は，走查回数が成膜特性に影響しないことが明ら かとなった。

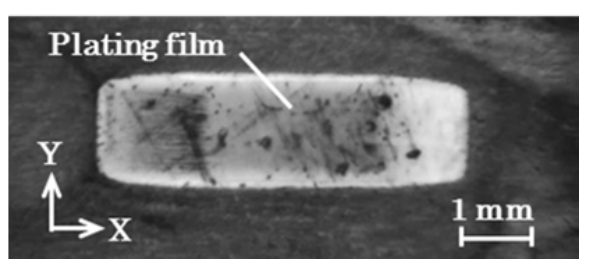

(a) Appearance of one time scanning

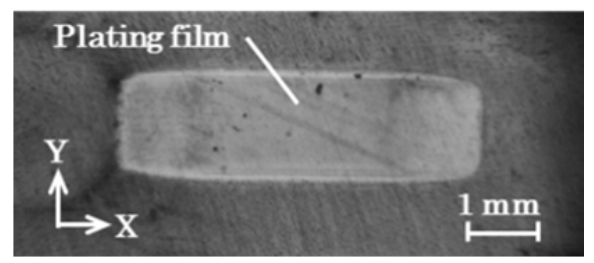

(b) Appearance of three-time scanning

Fig.18 Effect of lamination on film appearance

\section{7 結 論}

吸引工具による領域限定電解めっきの提案と検 証を行った結果，以下のことが明らかとなった。

(1) チタン電極の電極長さ消耗率は, 真鍮電極の 約半分となる。

(2) 真鍮電極を用いた $50 \mathrm{~mA}$ のめっぎは，ピッ 卜や焦げがめっき膜表面に発生しない.

(3) チタン電極では，走査速度が遅くなるにつれ て，めっき膜表面が粗くなる.

(4) 真鍮電極を用いた $50 \mathrm{~mA}$ の走查加工では, め 
つき膜表面の Ra が $0.1 \sim 0.2 \mu \mathrm{m}$ となる.

(5) 総通電時間が同じであれば，積層が膜厚に与 える影響は小さい。

\section{謝 辞}

本研究の一部は JSPS 科研費 25630021 の助成に よって行った.

\section{参考文献}

1) 岡田一誠, 下田浩平, 宮崎健史 : 金属ナノインキを 用いた微細配線形成技術，SEI テクニカルレビュ 一, No.168 (2006) pp.90-92.

2) 山名式雄 : めっき作業入門(増補版), 理工学社, (2003) pp.204-205.

3) 竹内宏充, 恒川好樹, 奥宮正洋, 河合豊 : 電解液噴 流によるノンマスキング部分めっき，日本金属学 会誌，No.62, No.4 (1998) pp.377-382.

4) M. Kunieda, R. Katoh, Y. Mori: Rapid Prototyping by Selective Electro Deposition Using Electrolyte Jet, CIRP Annals, Vol.47, No.1 (1998) pp.161-164.

5) K. Yamamura: Fabrication of Ultra Precision Optics by Numerically Controlled Local Wet Etching, Annals of the CIRP, Vol.56, No.1 (2007) pp.541-544.
6) K. Endo, W. Natsu: Proposal and Verification of Electrolyte Suction Tool with Function of Gap-width Detection, International Journal of Electrical Machining, No.19 (2014) pp.34-39.

7）丸山清 : めっき実務読本，日刊工業新聞社，(1983) pp.9-14, pp.22-23.

8) 岡村康弘: 設計現場で役立つめっきの基礎とノウハ ウ, 日刊工業新聞社, (2009) p.37.

9) 藤野武彦, 稲垣春雄 : めっき実用便覧, 工学図書株 式会社,(1978) pp.14-15.

10) C. W. Skaggs, and J. R. Jones: Unsupported Single Crystal Films of Germanium, J. Appl. Phys., Vol.35 (1964) p.3013.

11）日本めっき技術研究会：現場技術者のための実用 めっき( I )，梖書店, (1978) pp.89-97.

12) 丸山清: 初級めっき, 日刊工業新聞社, (1995) pp.46-47.

13) 中川威雄, 丸谷洋二 : 積層造形システム一三次元 コピー技術の新展開，工業調査会, (1996) pp.1-3.

14) 水野操, 平本知樹,神田沙織, 野村毅 : はじめての 3D プリンタ，技術評論社, (2013) p.16.

(2015 年 3 月 7 日受付) 